\title{
Evaluation of ozone profile and tropospheric ozone retrievals from GEMS and OMI spectra
}

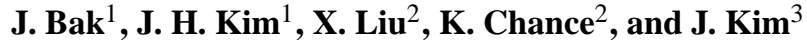 \\ ${ }^{1}$ Pusan National University, Busan, South Korea \\ ${ }^{2}$ Harvard-Smithsonian Center for Astrophysics, Cambridge, MA, USA \\ ${ }^{3}$ Yonsei University, Seoul, South Korea
}

Correspondence to: J. H. Kim (jaekim@pusan.ac.kr)

Received: 28 August 2012 - Published in Atmos. Meas. Tech. Discuss.: 18 September 2012

Revised: 9 January 2013 - Accepted: 14 January 2013 - Published: 5 February 2013

\begin{abstract}
South Korea is planning to launch the GEMS (Geostationary Environment Monitoring Spectrometer) instrument into the GeoKOMPSAT (Geostationary Korea Multi-Purpose SATellite) platform in 2018 to monitor tropospheric air pollutants on an hourly basis over East Asia. GEMS will measure backscattered UV radiances covering the $300-500 \mathrm{~nm}$ wavelength range with a spectral resolution of $0.6 \mathrm{~nm}$. The main objective of this study is to evaluate ozone profiles and stratospheric column ozone amounts retrieved from simulated GEMS measurements. Ozone Monitoring Instrument (OMI) Level 1B radiances, which have the spectral range $270-500 \mathrm{~nm}$ at spectral resolution of 0.42 $0.63 \mathrm{~nm}$, are used to simulate the GEMS radiances. An optimal estimation-based ozone profile algorithm is used to retrieve ozone profiles from simulated GEMS radiances. Firstly, we compare the retrieval characteristics (including averaging kernels, degrees of freedom for signal, and retrieval error) derived from the 270-330 nm (OMI) and 300$330 \mathrm{~nm}$ (GEMS) wavelength ranges. This comparison shows that the effect of not using measurements below $300 \mathrm{~nm}$ on retrieval characteristics in the troposphere is insignificant. However, the stratospheric ozone information in terms of DFS decreases greatly from OMI to GEMS, by a factor of $\sim 2$. The number of the independent pieces of information available from GEMS measurements is estimated to 3 on average in the stratosphere, with associated retrieval errors of $\sim 1 \%$ in stratospheric column ozone. The difference between OMI and GEMS retrieval characteristics is apparent for retrieving ozone layers above $\sim 20 \mathrm{~km}$, with a reduction in the sensitivity and an increase in the retrieval errors for GEMS. We further investigate whether GEMS can resolve
\end{abstract}

the stratospheric ozone variation observed from high vertical resolution Earth Observing System (EOS) Microwave Limb Sounder (MLS). The differences in stratospheric ozone profiles between GEMS and MLS are comparable to those between OMI and MLS below $\sim 3 \mathrm{hPa}(\sim 40 \mathrm{~km})$, except with slightly larger biases and larger standard deviations by up to $5 \%$. At pressure altitudes above $\sim 3 \mathrm{hPa}$, GEMS retrievals show strong influence of a priori and large differences with MLS, which, however, can be sufficiently improved by using better a priori information. The GEMS-MLS differences show negative biases of less than $4 \%$ for stratospheric column ozone, with standard deviations of $1-3 \%$, while OMI retrievals show similar agreements with MLS except for $1 \%$ smaller biases at middle and high latitudes.

Based on the comparisons, we conclude that GEMS will measure tropospheric ozone and stratospheric ozone columns with accuracy comparable to that of OMI and ozone profiles with slightly worse performance than that of OMI below $\sim 3 \mathrm{hPa}$.

\section{Introduction}

Atmospheric ozone is a key air pollutant that must be monitored routinely over the globe due to its huge impact on determining UV dose, air quality, radiation budget, and climate change (e.g., Liu and Trainer, 1987; Crutzen, 1996; Hauglustaine and Brasseur, 2001). The main goal of early space-based remote sensing was to observe daily total column ozone and stratospheric ozone profiles globally (e.g., McPeters et al., 1998). Total column ozone 
observations were accomplished with the successive launch of the Total Ozone Monitoring Spectrometer (TOMS), onboard Nimbus-7 (November 1978-May 1993), Meteor3 (August 1991-November 1994), ADEOS (July 1996June 1997), and Earth Probe (July 1996-December 2005) polar-orbiting satellites (Bhartia and Wellemeyer, 2002). The vertical distribution of stratospheric ozone has been observed from the Solar Backscatter UltraViolet (SBUV) on Nimbus 7 and National Oceanic and Atmospheric Administration (NOAA) weather satellites (1984 to now) (Bhartia et al., 1996). The TOMS and SBUV record has played an essential role in warning of the problem of ozone depletion over Antarctica and in assessing the recovery of the ozone layer since the Montreal Protocol came into effect (Salby et al., 2011; Kuttippurath et al., 2012). Since the middle 1990s, several UV/visible (and near infrared) spectrometers have been launched to continue the TOMS total ozone record, including the Global Ozone Monitoring Experiment (GOME), the SCanning Imaging Absorption Spectrometer for Atmospheric CHartograpY (SCIAMACHY), the Ozone Monitoring Instrument (OMI), GOME-2, and the Ozone Mapper Profiler Suite (OMPS). These low Earth orbit (LEO) instruments measure spectra over wide wavelength ranges (OMI: 270-500 nm, GOME: 240-790 nm, SCIAMACHY: 240-2380 nm, OMPS: $270-380 \mathrm{~nm}$ ), whereas TOMS and SBUV measure backscattered radiances at 6 and 12 discrete UV wavelength bands, respectively (European Space Agency, 1995; Bovensmann et al., 1999; Levelt et al., 2006). Thus they also measure additional tropospheric gases, including $\mathrm{NO}_{2}, \mathrm{H}_{2} \mathrm{CO}, \mathrm{H}_{2} \mathrm{O}, \mathrm{H}_{2} \mathrm{C}_{2} \mathrm{O}_{2}$, and $\mathrm{SO}_{2}$, which are indispensable for modeling tropospheric chemistry and forecasting air quality, and the halogen compounds $\mathrm{BrO}, \mathrm{OClO}$, and IO, which are responsible for stratospheric and tropospheric ozone depletion (Kuhl et al., 2008; Saiz-Lopez et al., 2007). These instruments have also shown their capability to measure ozone profiles into the troposphere, resulting from advanced radiometric and wavelength calibration and forward calculations (e.g., Munro et al., 1998; Van Oss et al., 2001; van der A et al., 2002; Liu et al, 2005, 2010a; Cai et al., 2012). Liu et al. (2010a), for example, demonstrated that OMI measurements contain up to $\sim 1.5$ degrees of freedom for signal in the troposphere, and the retrieval error of the tropospheric column ozone is normally within 2-5 DU (5$20 \%$ ). With the success of measuring air quality trace gases from polar-orbiting satellites, there is increasing interest in placing UV/visible spectrometers in geostationary orbit for much higher temporal resolution (e.g., hourly) (Bovensmann et al., 2004; Chance, 2005, 2006; Natraj et al., 2011; Zoogman et al., 2011; Bak et al., 2012a; Fishman et al., 2012).

The National Institute of Environmental Research (NIER/Ministry of Environment Korea) will launch GEMS in 2018 onboard the GeoKOMPSAT (Geostationary Korea Multi-Purpose SATellite) (Kim, 2012). GEMS is a spatial scanning UV/visible spectrometer to measure tropospheric pollutants including $\mathrm{O}_{3}, \mathrm{NO}_{2}, \mathrm{H}_{2} \mathrm{CO}, \mathrm{SO}_{2}$ and aerosols over the Asia-Pacific region. Creating an international constellation that includes GEMS, GMAP-Asia (Geostationary mission for Meteorology and Air Pollution, Japan), GEO-CAPE (Geostationary Coastal and Air Pollution Events, USA) and Sentinel-4 (European Space Agency) starting in the 20172020 time frame will provide global understanding of air quality and climate change issues.

The main objective of this study is to examine what ozone information can be achieved with the spectral characteristics of GEMS, employing its $300-500 \mathrm{~nm}$ spectral range. First, we determine whether or not GEMS achieves all of the tropospheric ozone information that is obtainable from OMI, over its $270-500 \mathrm{~nm}$ range. Second, we determine what stratospheric ozone information is available from the reduced GEMS spectral range. Due to wavelength-dependent absorption and Rayleigh scattering, the tropospheric information is mostly contained in the Huggins band between 300 and $340 \mathrm{~nm}$, whereas Hartley band information at wavelengths shorter than $\sim 290 \mathrm{~nm}$ mainly provides information for the altitude dependence of the ozone distribution above the stratospheric peak (Bhartia et al., 1996; Chance et al., 1997). The $300 \mathrm{~nm}$ lower limit of the GEMS spectral range is determined using the results of this study for tropospheric ozone, considering the difficulty and expense of building an instrument for GEO measurements with an extended range. However, accurate measurements of the stratospheric ozone profile and column ozone on an hourly basis would allow us to improve understanding of the impact of the change in the stratospheric ozone on the radiation budget and vertical structure of temperature in the troposphere (Haigh, 1994). Thus, it is very valuable to examine the potential capability of retrieving stratospheric profiles and stratospheric ozone column with proposed GEMS spectral coverage.

In this paper, we perform ozone profile retrievals using an optimal estimation-based technique (Rodgers, 2000; Liu et al., 2005, 2010a) from OMI Level 1B radiances (Dobber et al., 2008) with fitting windows within the $270-330 \mathrm{~nm}$ range, including the OMI fitting window, $270-330 \mathrm{~nm}$ and the eventual GEMS fitting window, $300-330 \mathrm{~nm}$. We first compare the retrieval sensitivity (averaging kernels and degrees of freedom for signal, DFS) and the retrieval quality (solution errors) from retrievals using different fitting windows. This comparison determines the $300 \mathrm{~nm}$ lower limit of the proposed GEMS spectral range for keeping tropospheric ozone information; it will ultimately show that how much stratospheric ozone information content is available with the GEMS reduced spectral range. Second, we validate the predicted GEMS results for stratospheric ozone profiles and columns using high vertical resolution ozone profiles made by Microwave Limb Sounder (MLS).

Our paper is organized as follows. The GEMS program is introduced in Sect. 2. The ozone profile retrieval algorithm used in this study is explained in Sect. 3. In Sect. 4, we analyze the retrieval characteristics of OMI and GEMS to evaluate how different spectral coverage affects 
the performance. Comparison of GEMS and OMI stratospheric ozone retrievals to MLS measurements is presented in Sect. 5. Section 6 presents conclusions on the accuracy of stratospheric ozone columns and profiles and of tropospheric ozone columns and profiles when measured with the planned GEMS spectral coverage.

\section{GEMS program}

GEMS is planned for launch in 2018 onboard GeoKOMPSAT, together with ABI (Advanced Baseline Imager) typed sensor and GOCI-2 (Geostationary Ocean Color Imager-2). The spatial domain of GEMS covers $5000 \mathrm{~km} \times 5000 \mathrm{~km}$ ranging from $5^{\circ} \mathrm{S}$ (Indonesia) to $45^{\circ} \mathrm{N}$ (south of the Russian border) and from $75^{\circ} \mathrm{E}$ to $145^{\circ} \mathrm{E}$. The nominal spatial resolution is $7 \mathrm{~km} \mathrm{~N} / \mathrm{S} \times 8 \mathrm{~km}$ E/W at Seoul. The N/S spatial resolution ranges from $4.9 \mathrm{~km}$ near the Equator to $9 \mathrm{~km}$ at the northern boundary of the domain while E/W resolution changes to keep the aspect ratio the same as that in Seoul. The spatial resolution at Seoul is 5.5 times better than the $13 \mathrm{~km} \times 24 \mathrm{~km}$ resolution of the state-of-the-art OMI LEO instrument at direct nadir. The planned GeoKOMPSAT longitude is $128.2^{\circ} \mathrm{E}$. The temporal resolution is $1 \mathrm{~h}$ during daytime. The spectral coverage of $300-500 \mathrm{~nm}$ in one channel is selected to focus on measurable tropospheric trace gases. A simple one-channel design helps to ensure the 7-10 yr lifetime requirements. Based on sensitivity studies of spectral resolution and signal-to-noise ratios to retrieve concentrations of $\mathrm{NO}_{2}, \mathrm{SO}_{2}, \mathrm{H}_{2} \mathrm{CO}$ and $\mathrm{O}_{3}$, the spectral resolution is selected to be $0.6 \mathrm{~nm}$. $\mathrm{SO}_{2}$ was the main driver in optimizing the resolution and signal-to-noise ratio requirements.

To ensure the accurate retrieval of trace gases, the accuracies on the wavelength and radiometric calibrations are required to be better than $0.01 \mathrm{~nm}$ and $4 \%$. Utilizing the solar Fraunhofer lines, the actual accuracy may be determined to much higher accuracy $(0.001 \mathrm{~nm}$ or better) (Caspar and Chance, 1997; Chance, 1998). The current requirement for polarization sensitivity is $<2 \%$. The impact of stray light on the UV/VIS measurements shall be less than $2 \%$ of the true signal. The performance of the system is comparable to or expected to be better than the existing LEO instruments. GEMS will provide the first hourly measurements of trace gases from space.

Accurate cloud pressure is an input for both ozone and trace gas retrieval algorithms. OMI has used the $\mathrm{O}_{2}-\mathrm{O}_{2}$ absorption near $477 \mathrm{~nm}$ and rotational Raman scattering in the range $346-352 \mathrm{~nm}$ to determine optical centroid pressure (OCP) (e.g., Acarreta et al., 2004; Joiner and Vasilkov, 2006; Vasilkov et al., 2004, 2008). GEMS includes both these spectral ranges. In addition, cloud information at much higher spatial resolution will be available from an ABI typed sensor within typically $7 \mathrm{~min}$ from GEMS data acquisition.

\section{Ozone profile retrieval algorithm}

We use the OMI ozone profile algorithm of Liu et al. (2010a) to retrieve ozone profiles from BUV measurements. This algorithm retrieves partial ozone columns at 24 layers from the surface to $\sim 60 \mathrm{~km}(0.22 \mathrm{hPa})$ using optimal estimation (OE) (Rodgers, 2000), optimally combining information from measurements with a priori information, depending on the sensitivity of the measurements. The principle of OE is to find the optimal solution by simultaneously and iteratively minimizing differences between measured and simulated radiances, and between the state and the a priori vector (e.g., an ozone profile), constrained by measurement and a priori error covariance matrixes, respectively (Rodgers, 2000). We perform retrievals from OMI radiances with OMI (270-330 nm) and GEMS (300-330 nm) spectral ranges respectively, after correcting some systematic biases derived from zonal mean MLS V2.2 data in the tropics, (Liu et al., 2010b). GEMS is designed to have spectral resolution of $0.6 \mathrm{~nm}$, while the spectral resolution of OMI is approximately $0.63 \mathrm{~nm}$ below $310 \mathrm{~nm}$ and 0.42 from $310-365 \mathrm{~nm}$ (Dobber et al., 2008). The change in the sensitivity due to the different spectral resolution of OMI and GEMS should be insignificant (Natraj et al., 2011). For simplicity of comparison, the effects of spectral resolution are ignored. The performance of the GEMS system is at least comparable to the existing similar LEO instruments, as pointed out in Sect. 2, and thus we use the OMI random-noise errors to construct measurement covariance error matrices for the retrieval performance of both OMI and GEMS. The inverse algorithm of Liu et al. (2010a) uses a monthly and zonal mean ozone profile climatology (McPeters et al., 2007) to define the a priori vector and the a priori error covariance matrix. We limit our study to solar zenith angles less than $85^{\circ} \mathrm{N}$ and retrievals with fitting RMS (i.e., root mean square of fitting residuals relative to measurement error) less than 3.

\section{Comparison of retrieval characteristics between OMI and GEMS}

This section shows the validity of the proposed GEMS spectral coverage for providing the adequate tropospheric ozone information as well as investigating the loss of the stratospheric ozone information from excluding shorter UV wavelengths. We perform ozone retrievals from one orbit of OMI UV measurements on 30 April 2006 with four spectral ranges (windows). The upper limit of these windows is fixed to be $330 \mathrm{~nm}$ while the lower limit varies from $270 \mathrm{~nm}$ to $310 \mathrm{~nm}$. We investigate the effect of different windows on ozone retrievals using their retrieval sensitivities and errors. We use the averaging kernel (AK), which characterizes how well the measurements probe the vertical distribution of atmospheric ozone information (Rodgers, 2000; Liu et al., 2005, 2010a) to represent the retrieval sensitivity. Each row of the AK matrix 

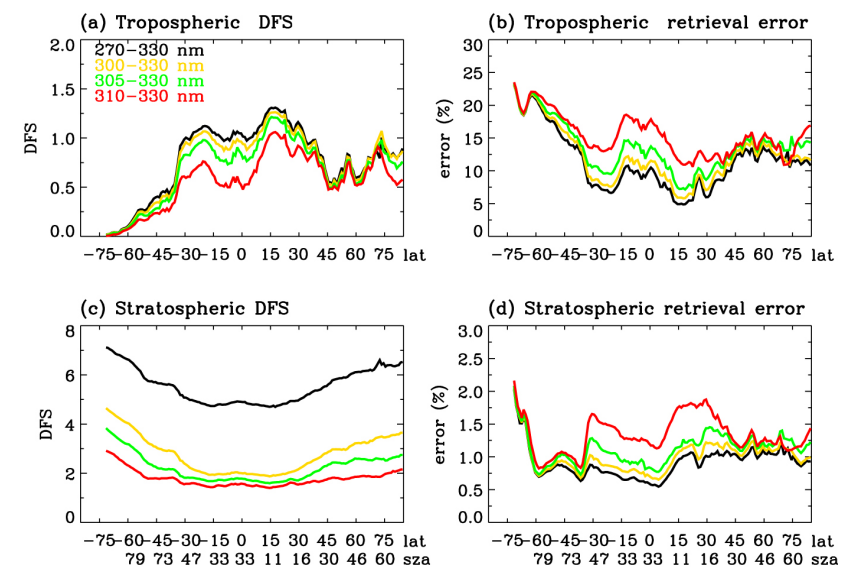

Fig. 1. Retrieval characteristics with the four spectral ranges between $270 \mathrm{~nm}$ and $330 \mathrm{~nm}$, calculated from OMI level 1b data in orbit 9522 on 30 April 2006. In the left panels (a, c), the means of degrees of freedom for signal (DFS) in the troposphere and stratosphere are plotted in $1^{\circ}$ latitude bins $\left(80^{\circ} \mathrm{S}\right.$ to $\left.80^{\circ} \mathrm{N}\right)$ with solar zenith angles given. The right panels $(\mathbf{b}, \mathbf{d})$ show the corresponding retrieval errors in tropospheric and stratospheric ozone columns, normalized to the a priori.

indicates the sensitivity of the retrieved ozone at each layer to the perturbation of ozone at all layers. It should be noted that, in addition to the spectral range, the AK matrix also depends strongly on the assumed a priori covariance and the measurement error, both of which are assumed to be the same here for both OMI and GEMS measurements. When the diagonal value of the AK matrix for a layer is unity, the measurements have sufficient information for ozone at that layer. The AKs can be used to estimate the vertical resolution (VR) of retrievals often specified as the full width at half maximum (FWHM). Each diagonal element of the AK gives the DFS for that layer, the number of independent pieces of information available at that layer from measurements. The DFS is a standard measure of the capability of atmospheric profile retrievals from satellite measurements (e.g., Liu et al., 2005, 2010a; Worden et al., 2007; Natraj et al., 2011; Bak et al., 2012a). The error budget in OE-based retrievals is estimated in terms of the random-noise error, smoothing error, solution error, and systematic errors (Rodgers, 2000). For retrieval error, we use the solution error defined as the root-sum-square of the random noise and the smoothing error; the random noise from the measurements and the smoothing errors due to the limited vertical resolution of retrievals and the use of a priori information are directly estimated from the retrievals (Liu et al., 2005, 2010a). Solution error for UV retrievals is typically dominated by the smoothing errors (Liu et al., 2005, 2010a).

Figure 1 shows how the retrieval characteristics for the stratospheric and tropospheric column ozone change for the different spectral windows. The integrated DFS values/retrieval errors in the troposphere and stratosphere are plotted in $1^{\circ}$ latitude bins, with corresponding solar zenith angles. The stratospheric DFS shows larger values at higher latitudes, mainly because the optical path length through the stratospheric ozone layer becomes longer due to larger solar zenith angles. Conversely, the tropospheric DFS values tend to be smaller at larger solar zenith angles due to the decreased penetration of UV radiation into the deep troposphere (Liu et al., 2010a). In addition, the change of the tropospheric DFS with respect to latitude is much more complicated because of the influences of clouds, aerosols, and surface reflectivity. There is no distinct loss in the tropospheric DFS of the $300-330 \mathrm{~nm}$ relative to that from $270-330 \mathrm{~nm}$. However, the tropospheric DFS values are reduced by a factor of 2 with the change of the lower limit from $270 \mathrm{~nm}$ to $310 \mathrm{~nm}$, for most of the tropics. The corresponding retrieval errors show negligible increase with the change of window from OMI to GEMS (300-330 nm), but show significant increase for the 305-330 nm window. At middle/high latitudes, tropospheric column ozone retrievals seem to be less affected by the spectral coverage used due to the limited light penetration at wavelengths less than $\sim 300 \mathrm{~nm}$ into the troposphere at large solar zenith angle. This result suggests that the lower limit $300 \mathrm{~nm}$ of the proposed GEMS spectral coverage is acceptable for simplifying the design of the spectrometer as well as minimizing loss in tropospheric ozone information. However, the lower limit for GEMS leads to a serious loss of the stratospheric ozone information compared to OMI. The average stratospheric DFS values decrease from $\sim 6$ for OMI to $\sim 3$ for GEMS although the change in corresponding stratospheric ozone column retrieval errors is negligible.

We further examine altitude regions where excluding measurements below $300 \mathrm{~nm}$ causes much loss of stratospheric information. In Fig. 2, the performances for retrieving ozone profiles from OMI (blue lines) and GEMS (red lines) are compared with respect to the mean AKs and mean relative retrieval errors in low and mid-latitude regions, respectively. In the atmosphere below $\sim 20 \mathrm{~km}$, AKs for each instrument show similar distributions. This illustrates that GEMS contains not only most of the tropospheric ozone information compared to OMI, but also most of the capability to separate tropospheric from stratospheric ozone columns. OMI AKs have well-defined peaks from $\sim 25 \mathrm{~km}$ to $45 \mathrm{~km}$, with the highest DFS values. GEMS AK plots have very broad peaks above $30 \mathrm{~km}$, with rapid reduction of their DFS values. The GEMS profile retrieval errors increase by $\sim 1-2 \%$ (from $2 \%$ to $4 \%$ ) for most of the stratosphere and by $3-4 \%$ (from 3-4\% to 6-8\%) above $40 \mathrm{~km}$. Above $30 \mathrm{~km}$, the error increase is significant as the retrieval error almost doubles. In addition, Fig. 2 shows the comparison of the retrieval errors with a priori errors (black line). The magnitude of GEMS retrieval errors is very close to a priori error above $\sim 40 \mathrm{~km}$, indicating the weak retrieval sensitivity and the strong influence of a priori on the retrievals. It should be noted that, despite GEMS's very weak vertical sensitivity above $\sim 25 \mathrm{~km}$ based on averaging kernels, the increases in retrieval errors 

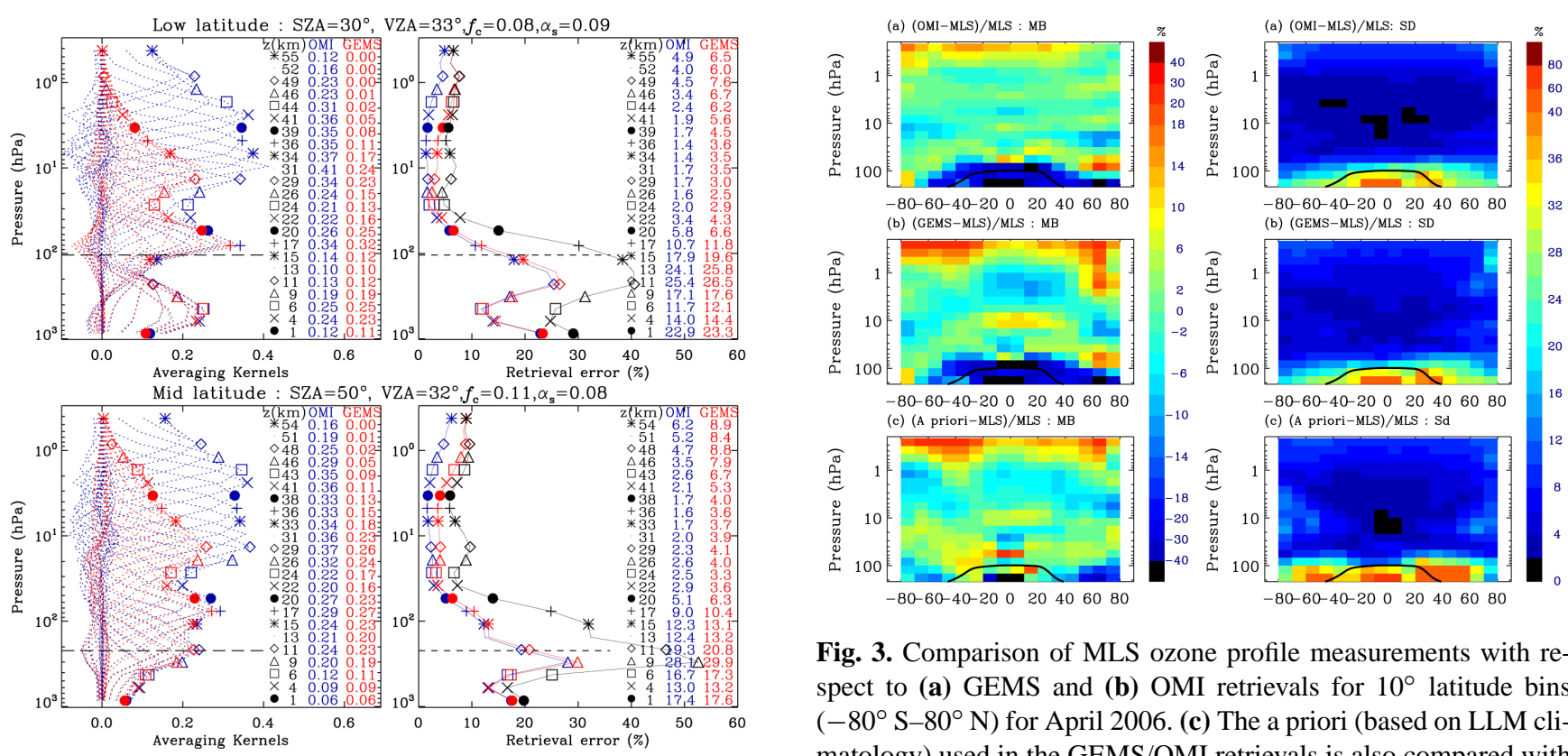

Fig. 3. Comparison of MLS ozone profile measurements with respect to (a) GEMS and (b) OMI retrievals for $10^{\circ}$ latitude bins $\left(-80^{\circ} \mathrm{S}-80^{\circ} \mathrm{N}\right)$ for April 2006. (c) The a priori (based on LLM climatology) used in the GEMS/OMI retrievals is also compared with MLS. Left and right panels show the mean biases (MB) and the $1 \sigma$ standard deviations (SD) of the relative differences as functions of MLS vertical layers $(0.22-215 \mathrm{hPa})$. The black line indicates the position of the mean tropopause during April 2006.

and GEMS (red) retrievals, for low latitude $\left(30^{\circ} \mathrm{S}-30^{\circ} \mathrm{N}\right.$ : upper panel) and mid-latitude $\left(30^{\circ} \mathrm{S} / \mathrm{N}-60^{\circ} \mathrm{S} / \mathrm{N}\right.$ : lower panel). The associated a priori error is also plotted with black line in right figures. In this analysis, we only consider pixels with cloud fraction of less than 0.3 and surface albedo less than $20 \%$. The caption includes the average conditions for low/mid-latitude pixels: solar zenith angle (SZA), viewing zenith angle (VZA), cloud fraction $\left(f_{\mathrm{c}}\right)$, and surface albedo $\left(\alpha_{\mathrm{S}}\right)$. The dashed line denotes the mean tropopause height. The first column of each legend gives the center altitudes of the 24 layers. The other two columns in the left figures give DFS; in the right figures they give relative retrieval errors (\%).

appear to be small. This is because the a priori error for this altitude range is already very small $(5-7 \%)$; the retrieval errors also remain very small irrespective of spectral range, and the comparison of retrieval error might not reflect all the impact of reduced spectral range.

\section{Evaluation of ozone retrievals against MLS}

In this section, we assess whether information available from GEMS measurements is enough to resolve the true variability of the stratospheric ozone profiles. The MLS V3.3 standard $\mathrm{O}_{3}$ products for April 2006 are used as reference values. We collocate MLS and OMI pixels within $\pm 0.5^{\circ}$ in both latitude and longitude and $500 \mathrm{~s}$ in time, giving $\sim 30000$ collocated pixels. We apply data screening to exclude bad retrievals from both profile algorithms using criteria described in Sect. 3 for OMI and in Sect. 5.1 for MLS. V3.3 $\mathrm{MLS} \mathrm{O}_{3}$ profiles are recommended for use from 261$0.02 \mathrm{hPa}$ (Livesey et al., 2011). They are provided at 12 pressure levels per pressure decade from $1 \mathrm{hPa}$ and higher pres-

sures $(\sim 1.3 \mathrm{~km}$ resolution), 6 per decade from $0.1-1 \mathrm{hPa}$ $(\sim 2.5 \mathrm{~km}$ resolution), and 3 per decade at lower pressures. For comparisons, the MLS profiles of volume mixing ratio are converted into partial ozone columns in Dobson units (DU, $1 \mathrm{DU}=2.687 \times 10^{16}$ molecules $\mathrm{cm}^{-2}$ ). V3.3 MLS and OMI/GEMS partial columns are interpolated into the MLS $\mathrm{V} 2.2$ retrieval grids. The vertical spacing of the V2.2 pressure grid is similar to OMI, $\sim 2.5 \mathrm{~km}$ below $0.1 \mathrm{hPa}$, and hence the interpolation error on the difference between OMI and MLS retrieved profiles is expected to be smaller when comparing them on this grid.

In Figs. 3-7 we compare the OMI and GEMS profiles and column ozone to MLS from $215 \mathrm{hPa}$ to $0.2 \mathrm{hPa}$, the vertical range recommended by Liu et al. (2010b) for comparing OMI and MLS v2.2 ozone profiles. The comparison approach largely follows Liu et al. (2010b).

\subsection{MLS data}

MLS is on board the Aura platform with OMI, so the effect of the spatiotemporal variability on comparisons with OMI (and GEMS) is relatively small (Liu et al., 2010b). MLS measures microwave thermal emission from many molecules; ozone profiles are derived from emission near $240 \mathrm{GHz}$. MLS is limb-viewing and thus has higher vertical resolution but much sparser horizontal coverage than OMI. The V3.3 MLS $\mathrm{O}_{3}$ data used here are from the NASA Goddard Space Flight Center Earth Sciences (GES) Data and Information Services Center (DISC). Although extensive validation results for the 


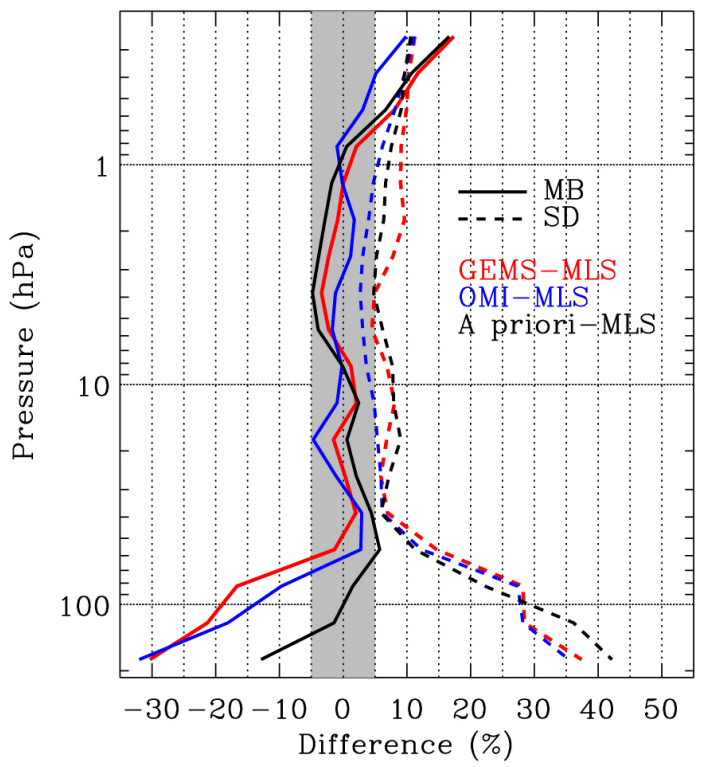

Fig. 4. Mean biases and $1 \sigma$ standard deviations calculated using all the collocated profiles globally for April 2006.

V3.3 MLS ozone product have not been released, they are not expected to differ significantly from those for the V2.2 data (Livesey et al., 2011). Based on the V2.2 MLS validation papers by Froidevaux et al. (2008), Jiang et al. (2007), and Livesey et al. (2008), the precision of the ozone profiles is $\sim 5 \%$ for much of the stratosphere, increasing to $\sim 10 \%$ at the lowest stratospheric altitudes. The precision of the stratospheric column ozone down to $215 \mathrm{hPa}$ is about $2 \%$. To exclude bad retrievals, we reject profiles with negative ozone values less than -0.15 ppmv over $45-261 \mathrm{hPa}$ pressure range and consider profiles having even status value, quality higher than 0.6 , convergence lower than 1.18 , and precision value higher than 0 , according to the V3.3 data screening recommendations by Livesey et al. (2011).

\subsection{Comparison of stratospheric profiles}

We analyze the statistical differences of GEMS/OMI retrievals and a priori relative to MLS profiles for April 2006. A priori profiles are based on the monthly zonal mean ozone profile climatology of McPeters et al. (2007) (hereafter the "LLM" climatology). The absolute difference is normalized to MLS measurements to define the relative differences. Figure 3 shows the mean biases versus $10^{\circ}$ latitudinal bins at each MLS layer from $0.22-215 \mathrm{hPa}$ and the corresponding $1 \sigma$ standard deviations. OMI and GEMS retrievals have similar agreement with MLS around the mean tropopause (black line), but show some large negative biases, usually within $-20 \%$ to $-40 \%$ below $68 \mathrm{hPa}$ at low/mid-latitude. The standard deviations of the biases range from $20 \%$ to $50 \%$. These large differences in the tropopause region likely originate from insufficient vertical resolution of OMI to capture the
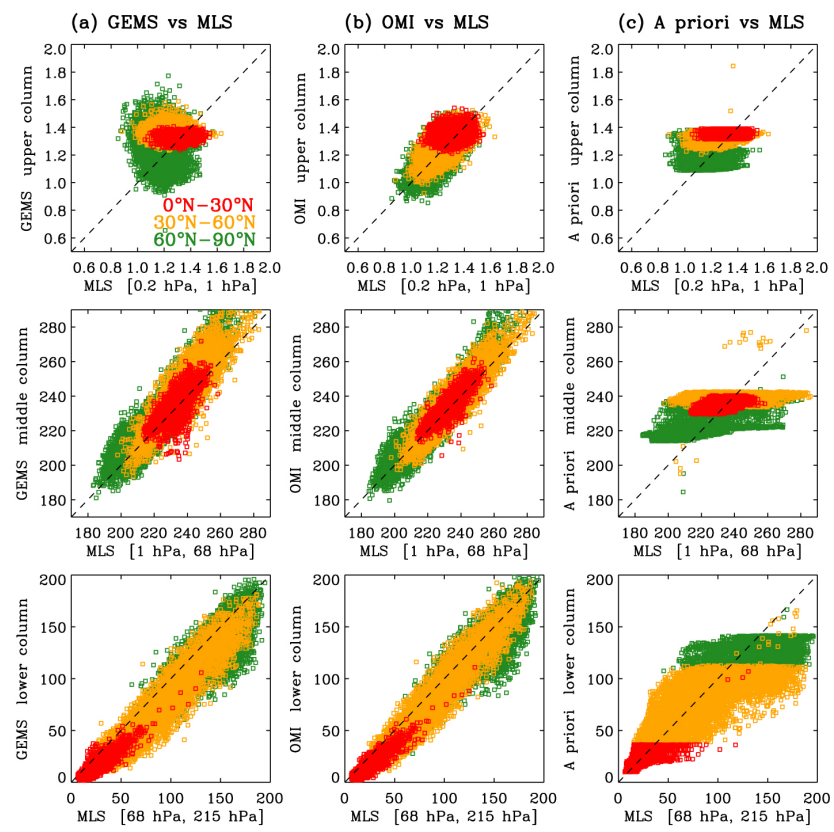

Fig. 5. Scatter plots of (a) GEMS versus MLS, (b) OMI versus MLS, and (c) a priori versus MLS for partial column ozone at three vertical layers between $0^{\circ} \mathrm{N}$ and $90^{\circ} \mathrm{N}$ for April 2006. The layers are bounded by $0.2,1,68$, and $215 \mathrm{hPa}$. Color coding for different latitude bins is indicated in the legend on the top left panel. Dashed lines are unit slope.

small-scale changes observed by MLS. A priori biases have opposite signs around tropical tropopause, mostly positive, indicating that some of the differences (where ozone values are relatively small) are due to systematic biases between OMI/GEMS and MLS.

The largest impact of not using measurements below $300 \mathrm{~nm}$ is mainly found for pressures less than $\sim 3 \mathrm{hPa}$ $(\sim 40 \mathrm{~km})$ where there is no peak in the AKs for GEMS and the retrieval error is very close to a priori (Fig. 2). GEMS retrievals show the large biases of $\sim 20 \%$ down to $3 \mathrm{hPa}$, especially at high latitude. The GEMS positive mean biases at these layers are consistent with those of the a priori, indicating the strong influence of the a priori on retrievals. Moreover, the GEMS retrievals have more vertical oscillation in the biases between $1-50 \mathrm{hPa}$ especially in $30^{\circ} \mathrm{S}-30^{\circ} \mathrm{N}$, due to reduced vertical sensitivity and stronger a priori influence relative to OMI retrievals. For example, the tropical region shows distinct negative bias of $\sim-10 \%$ at $\sim 2 \mathrm{hPa}$ and positive bias of $\sim 10 \%$ at $\sim 10 \mathrm{hPa}$ where OMI is retrieved within $\pm 5 \%$ with respect to MLS.

Figure 4 shows globally averaged profiles of mean biases and standard deviations for April 2006. From 60 to $100 \mathrm{hPa}$, the global mean biases of GEMS show $5 \%$ larger negative mean biases than OMI. From $1 \mathrm{hPa}$ to $0.2 \mathrm{hPa}$, the global biases range from $\sim 0 \%$ to $17 \%$ for GEMS and from $0 \%$ to $10 \%$ for OMI. The global mean bias profiles remain within $\pm 5 \%$ between $1 \mathrm{hPa}$ and $60 \mathrm{hPa}$ for both OMI and GEMS 

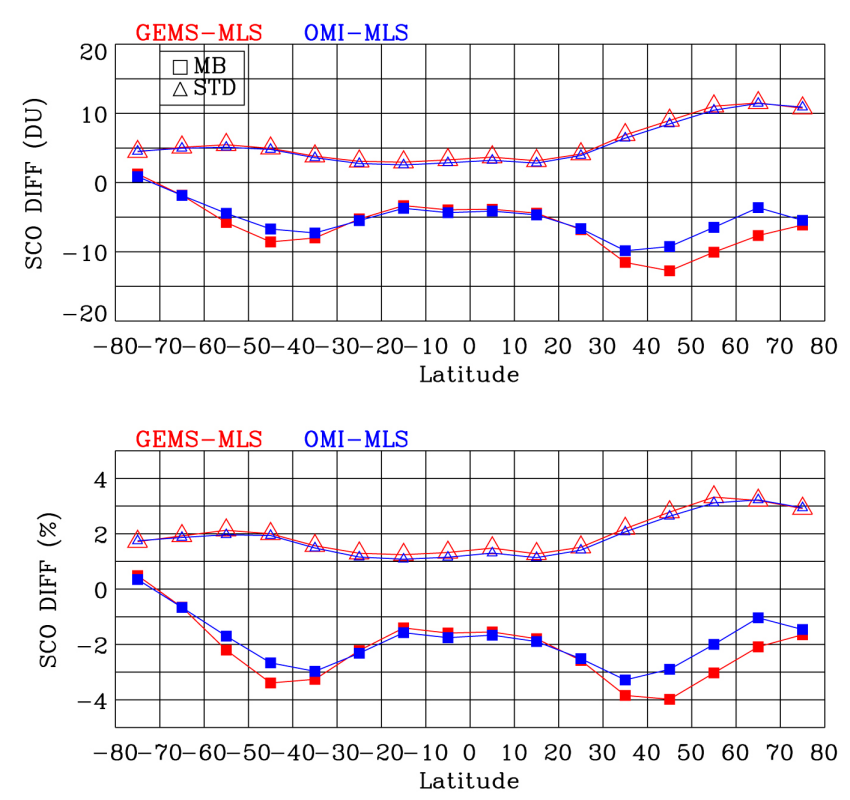

Fig. 6. Comparison of stratospheric column ozone (SCO) above $215 \mathrm{hPa}$ in $10^{\circ}$ latitude bins for April 2006. The upper panel and lower panel display the mean biases (square symbol) and standard deviations (triangle symbol) for absolute differences (DU) and relative differences $(\%)$, respectively. The relative difference is defined as the absolute difference $\times 100 \% /$ MLS.

retrievals. However, the corresponding standard deviations of GEMS mean biases are found to be slightly larger than those for OMI, by up to $\sim 5 \%$.

\subsection{Comparison of sub-column $\mathrm{O}_{3}$ in the stratosphere}

In order to better understand the information obtained with different spectral windows, we explore the retrieval performance for sub-layer column $\mathrm{O}_{3}$. The profiles are integrated into the three pressure layers, bounded by the $0.2,1,68$, and $215 \mathrm{hPa}$ pressure levels. Figure 5a gives scatter plots of GEMS versus MLS layer column ozone grouped into low $\left(0^{\circ}-30^{\circ}\right)$, middle $\left(30^{\circ}-60^{\circ}\right)$, and high $\left(60^{\circ}-90^{\circ}\right)$ latitude bands for the Northern Hemisphere. Figure $5 \mathrm{~b}$ and $\mathrm{c}$ give OMI and a priori with respect to MLS. The comparison statistics (mean biases, standard deviations, and correlation coefficients) are summarized in Table 1.

First, the weak sensitivity of GEMS measurements to $0.2-$ $1 \mathrm{hPa}$ layer column $\mathrm{O}_{3}$ (upper column $\mathrm{O}_{3}$ ) is clearly found, with a correlation coefficient of $\sim 0$ with MLS. In this layer, the scatter of GEMS versus MLS is very similar to that of a priori and MLS, especially in the low/mid-latitudes. In contrast, OMI contains more information content than GEMS due to the inclusion of spectral information below $300 \mathrm{~nm}$, as seen from the positive correlation of more than 0.6 with MLS above $30^{\circ} \mathrm{N}$. Second, both OMI and GEMS retrievals show considerable sensitivity to middle and lower layer column $\mathrm{O}_{3}$. They show much better agreement with MLS than with
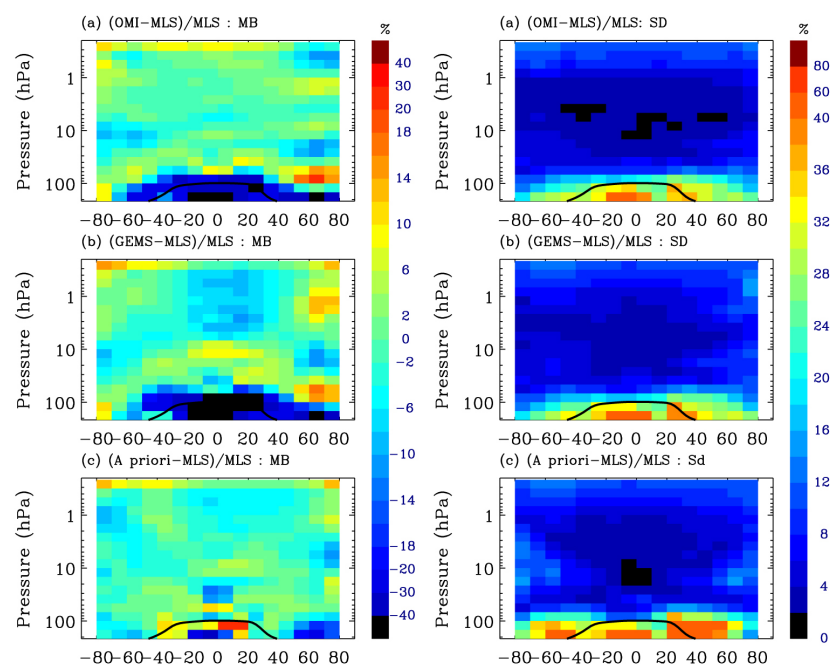

Fig. 7. Same as Fig. 3, but for the use of ML climatology (2012) as a priori data.

a priori. However, the GEMS retrievals have slightly weaker correlation with MLS than does OMI even below $1 \mathrm{hPa}$. The GEMS performance for the middle column $\mathrm{O}_{3}$ slightly increases the positive biases by $\sim 0.8 \mathrm{DU}(0.4 \%)$ at low latitude and $\sim 4 \mathrm{DU}(1.5 \%)$ at middle/high latitude in relation to OMI. For the lower column $\mathrm{O}_{3}$, the largest difference between OMI and GEMS with MLS is at mid-latitude: mean biases increase from $-9.1 \mathrm{DU}(-13 \%)$ for OMI to $-15.5 \mathrm{DU}$ $(-20.8 \%)$ for GEMS. The high latitude also shows the significant increase in the absolute mean biases from $-7.9 \mathrm{DU}$ to $-12.2 \mathrm{DU}$. In contrast, the low latitude mean biases increase by $0.5 \mathrm{DU}(3 \%)$ due to the exclusion below $300 \mathrm{~nm}$. In this pressure range, the ozone is mostly retrieved in the upper troposphere in the tropics and is in the lower stratosphere at middle/high latitudes. In addition, the lower column $\mathrm{O}_{3}$ is much smaller in the tropics than those at middle and high latitudes. Therefore the middle/high latitude lower column $\mathrm{O}_{3}$ is more strongly impacted by the exclusion below $300 \mathrm{~nm}$ than the low latitude. Overall, the impact of the 270 to $300 \mathrm{~nm}$ spectral information on the comparison of retrievals with MLS is found to be larger in the lower column $\mathrm{O}_{3}$ than middle column $\mathrm{O}_{3}$ despite the negligible difference in the retrieval sensitivity around the tropopause between OMI and GEMS as shown in Fig. 2. This is because the relative a priori error (thus the retrieval error) for the lower $\mathrm{O}_{3}$ column is significantly larger than that for the middle column $\mathrm{O}_{3}$.

\subsection{Comparison of stratospheric column ozone}

We compare stratospheric column ozone (SCO) from 0.2 to $215 \mathrm{hPa}$ as function of latitude in Fig. 6. Both OMI and GEMS SCO are generally negatively biased with respect to MLS. In Table 1, we indicate the positive biases above $68 \mathrm{hPa}$ and negative biases below it for sub-layer column $\mathrm{O}_{3}$ between $215 \mathrm{hPa}$ and $0.2 \mathrm{hPa}$. Therefore, the SCO 
Table 1. Comparison statistics corresponding to Fig. 5.

\begin{tabular}{|c|c|c|c|c|c|c|}
\hline \multicolumn{7}{|c|}{ Upper column $\mathrm{O}_{3}[0.2-1 \mathrm{hPa}]$} \\
\hline Lat. & $\operatorname{Bias} \pm 1 \sigma^{\mathrm{a}}$ & $R^{\mathrm{b}}$ & $\operatorname{Bias} \pm 1 \sigma$ & $R$ & $\operatorname{Bias} \pm 1 \sigma$ & $R$ \\
\hline $0^{\circ} \mathrm{N}-30^{\circ} \mathrm{N}$ & $0.02 \pm 0.07(1.7 \pm 5.3)$ & 0.04 & $0.04 \pm 0.07(3.2 \pm 5.5)$ & 0.19 & $0.04 \pm 0.07(3.0 \pm 5.4)$ & 0.02 \\
\hline $30^{\circ} \mathrm{N}-60^{\circ} \mathrm{N}$ & $0.09 \pm 0.10(7.7 \pm 8.1)$ & -0.06 & $0.02 \pm 0.07(1.9 \pm 6.1)$ & 0.64 & $0.07 \pm 0.08(6.1 \pm 7.0)$ & 0.28 \\
\hline \multirow[t]{3}{*}{$60^{\circ} \mathrm{N}-90^{\circ} \mathrm{N}$} & $0.10 \pm 0.18(9.8 \pm 15.5)$ & -0.21 & $-0.01 \pm 0.08(-0.9 \pm 7.2)$ & 0.64 & $0.04 \pm 0.12(3.9 \pm 10.7)$ & 0.04 \\
\hline & \multicolumn{6}{|c|}{ Middle column $\mathrm{O}_{3}[1-68 \mathrm{hPa}]$} \\
\hline & \multicolumn{2}{|l|}{ GEMS-MLS } & \multicolumn{2}{|l|}{ OMI-MLS } & \multicolumn{2}{|l|}{ A priori-MLS } \\
\hline Lat. & $\operatorname{Bias} \pm 1 \sigma$ & $R$ & $\operatorname{Bias} \pm 1 \sigma$ & $R$ & $\operatorname{Bias} \pm 1 \sigma$ & $R$ \\
\hline $0^{\circ} \mathrm{N}-30^{\circ} \mathrm{N}$ & $2.23 \pm 3.65(1.0 \pm 1.6)$ & 0.83 & $1.42 \pm 2.86(0.6 \pm 1.2)$ & 0.89 & $2.76 \pm 5.54(1.2 \pm 2.4)$ & 0.44 \\
\hline $30^{\circ} \mathrm{N}-60^{\circ} \mathrm{N}$ & $4.00 \pm 7.10(1.7 \pm 3.0)$ & 0.88 & $0.44 \pm 5.65(0.2 \pm 2.4)$ & 0.92 & $1.22 \pm 12.52(0.7 \pm 5.4)$ & 0.04 \\
\hline Lat. & $\operatorname{Bias} \pm 1 \sigma$ & $R$ & $\operatorname{Bias} \pm 1 \sigma$ & $R$ & $\operatorname{Bias} \pm 1 \sigma$ & $R$ \\
\hline $0^{\circ} \mathrm{N}-30^{\circ} \mathrm{N}$ & $-7.09 \pm 3.72(-40.7 \pm 15.7)$ & 0.91 & $-6.53 \pm 3.62(-37.3 \pm 16.3)$ & 0.92 & $0.17 \pm 5.58(4.1 \pm 26.8)$ & 0.75 \\
\hline $30^{\circ} \mathrm{N}-60^{\circ} \mathrm{N}$ & $-15.48 \pm 11.96(-20.8 \pm 16.0)$ & 0.94 & $-9.09 \pm 11.18(-13.0 \pm 15.3)$ & 0.96 & $-5.45 \pm 25.32(1.6 \pm 30.6)$ & 0.70 \\
\hline $60^{\circ} \mathrm{N}-90^{\circ} \mathrm{N}$ & $-12.19 \pm 15.27(-8.4 \pm 10.7)$ & 0.81 & $-7.88 \pm 14.67(-5.3 \pm 10.2)$ & 0.83 & $-17.03 \pm 21.00(-10.4 \pm 13.9)$ & 0.43 \\
\hline
\end{tabular}

${ }^{\mathrm{a}}$ Mean biases and $1 \sigma$ standard deviations are in DU (values in parentheses are in percent). ${ }^{\mathrm{b}}$ Correlation coefficient.

negative biases might be largely contributed by the retrievals in the tropospheric region. The OMI biases relative to MLS V3.3 for April 2006 investigated in this study are within $10 \mathrm{DU}(-3 \%)$ that are larger compared to the biases relative to MLSV2.2 for 2006 within 5.5 DU (-2\%) (Liu et al., 2010b). The mean biases show their maximum values in mid-latitudes; their standard deviations increase generally with latitude. The GEMS/OMI biases in the tropics are less than $-2 \%$. The main difference in OMI and GEMS stratospheric column ozone is found at latitude bands above $35^{\circ} \mathrm{N} / \mathrm{S}$; GEMS biases are larger than OMI biases by up to $4 \mathrm{DU}(\sim 1 \%)$. Standard deviations for the GEMS and MLS differences are similar to those for the OMI and MLS differences, varying from $1 \%$ to $3 \%$, depending on latitude.

\section{Conclusions}

We investigate the retrieval performance for ozone profiles from OMI level $1 \mathrm{~B}$ data using different spectral windows (OMI: 270-330 nm, GEMS: 300-330 nm), in order to identify the weakness of excluding measurements below $300 \mathrm{~nm}$ on retrievals. This exclusion makes little difference in both retrieval sensitivity and the retrieval error for the tropospheric ozone profile/column retrieval. The change of the lower spectral limit from $300 \mathrm{~nm}$ to $310 \mathrm{~nm}$ leads to a significant reduction in the tropospheric DFS with a significant increase in the associated retrieval errors. Therefore, the proposed GEMS

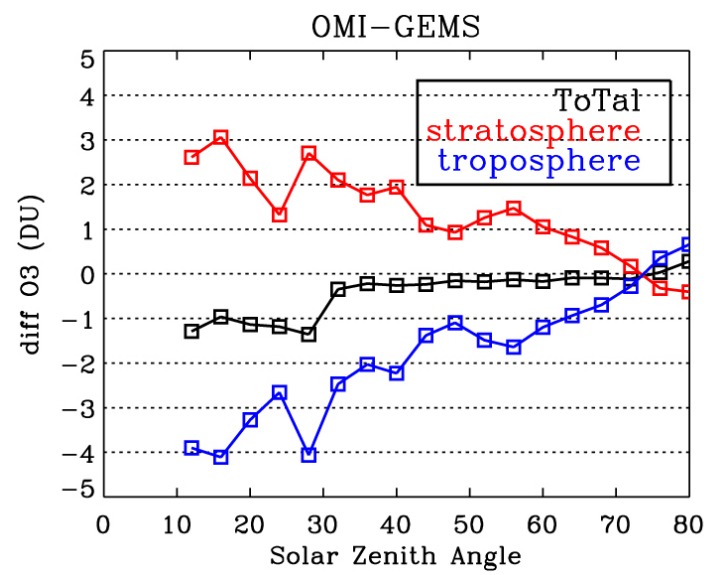

Fig. 8. Direct comparisons of total/stratospheric/tropospheric ozone column between OMI and GEMS. The mean biases of OMI-GEMS ozone columns from retrievals of orbit 9522 on 30 April 2006 are plotted as a function of solar zenith angle.

spectral coverage is nearly optimal for maximizing the tropospheric ozone information available from UV measurements. However, the exclusion of spectral information below $300 \mathrm{~nm}$ substantially reduces the stratospheric DFS. The loss of stratospheric ozone information occurs mostly above $\sim 20 \mathrm{~km}$. The stratospheric column retrieval errors do not vary much with spectral coverage, but the errors at individual layers show significant increases. 
GEMS retrievals have, on average, three independent pieces of information in the stratosphere. In order to determine whether the three independent pieces are enough to report the stratospheric ozone profiles and stratospheric column ozone, we further evaluate both OMI and GEMS retrievals using high-resolution MLS V3.3 standard $\mathrm{O}_{3}$ product for April 2006. GEMS profiles show an excellent agreement with MLS data except for the tropopause region and altitudes above $\sim 3 \mathrm{hPa}$ : the global mean biases are within $\pm 5 \%$ with standard deviation of $5-10 \%$. This agreement is comparable to that of OMI and MLS except with larger standard deviations by up to $5 \%$. The weakness of GEMS profile retrievals is mainly found above $\sim 3 \mathrm{hPa}$. Because GEMS contains little vertical information above $3 \mathrm{hPa}$ as shown in Fig. 2, comparisons at layers above $3 \mathrm{hPa}$ show a large dependence of GEMS retrievals on a priori (LLM climatology), with the large differences corresponding to large differences between a priori and MLS. This suggests that the large GEMS ozone biases above $3 \mathrm{hPa}$ can be reduced by using better a priori information. A priori information used in this study is basically from the LLM climatology, derived using ozone measurements from ozonesondes (1988-2002), SAGE II (19882001), and Upper Atmosphere Research Satellite (UARS) MLS (1991-99). Figure 7 is the same as Fig. 3, except for using a priori data from the updated version of the LLM climatology presented by McPeters and Labow (2012) (hereafter, the "ML climatology"). This climatology is formed from the Aura MLS V3.3 data (2004-2010) and ozonesonde data (1988-2010). We found that the a priori information from the ML climatology greatly improves the GEMS/OMI retrievals above $\sim 3 \mathrm{hPa}$. Even for below $3 \mathrm{hPa}$, some improvements are found. However, the ML climatology tends to increase the differences between retrievals and ozonesonde measurements generally in the upper troposphere and lower stratosphere (UTLS) compared to the LLM climatology (not shown here). We will further investigate the various a priori data to select the optimal one for GEMS ozone profile retrievals in a future study.

Both GEMS and OMI retrievals below $68 \mathrm{hPa}$ show large mean biases with MLS and their large standard deviations, but GEMS has larger biases, especially at mid-latitudes. The altitude region below $68 \mathrm{hPa}$ is associated with the UTLS region where atmospheric dynamical processes strongly influence ozone variability. The LLM climatology only represents ozone variances as function of month and latitude and thereby is not suitable for representing the ozone variances in the UTLS region. Therefore, some standard deviations of the differences between OMI/GEMS and MLS might be related to differences between a priori and true states. Therefore, there is substantial room for improving ozone retrievals in the UTLS region by using the dynamically oriented a priori information. The tropopause height dependent (TB) climatology of ozone profiles for the OMI retrieval algorithm is under development by Bak et al. (2012b). We will investigate the use of TB climatology for GEMS retrievals in fu- ture work. Furthermore, we indicated that the large negative biases around tropopause are associated with the systematic biases between OMI/GEMS and MLS V3.3 retrievals.

As the total ozone columns are mostly determined from the radiance measurements at the longer wavelengths (> $300 \mathrm{~nm}$ ), which are in both GEMS and OMI spectral range, the similar OMI/GEMS SCO retrieval performance indirectly demonstrates that the tropospheric ozone column retrieval performance is similar to that of OMI. Furthermore, we directly demonstrated that the GEMS performance can provide the tropospheric ozone retrieval sensitivity at least comparable to OMI. Nevertheless, even a small error or bias in the stratospheric ozone column could translate into a large error or bias in the tropospheric ozone column, simply because the tropospheric component is usually a small part of the total column. In order to check the differences in the tropospheric ozone columns due to the different spectral range, the direct comparison of total/stratospheric/tropospheric ozone columns between OMI and GEMS is performed. The mean biases between retrievals are plotted as a function of solar zenith angle in Fig. 8. Comparisons show the larger differences of retrievals at smaller solar zenith angles (tropics) where the lower limit of the spectral coverage plays a significant role in the retrieval characteristics as shown in Fig. 1. The total column ozone comparison shows the mean difference of $\sim 0 \mathrm{DU}$ at solar zenith angle greater than $40^{\circ}$; GEMS tropospheric (stratospheric) column ozone retrievals are negatively (positively) biased relative to OMI within $\sim 2 \mathrm{DU}$. On the other hand, bias of $\sim 3 \mathrm{DU}(\sim 1 \%)$ in the stratospheric ozone column and bias of $\sim-1 \mathrm{DU}(\sim 0.5 \%)$ in total ozone column translate into bias of $\sim 4 \mathrm{DU}(\sim 10 \%)$ in the tropospheric ozone column at small solar zenith angle of less than $30^{\circ}$. This result illustrates that little changes of the retrieval characteristics need to be carefully considered in developing the GEMS algorithm for the tropospheric ozone retrievals.

This study contributed to determining the projected GEMS spectral coverage for tropospheric ozone retrievals and demonstrated the possibility of retrieving the stratospheric ozone profiles from GEMS spectral information despite the lack of Hartley band information.

Acknowledgements. This research was supported by the EcoInnovation Program of KEITI (ARQ201204015), Korea. Research at the Smithsonian Astrophysical Observatory was funded by NASA and the Smithsonian Institution. We acknowledge OMI and MLS science teams for providing the satellite data used in this study.

Edited by: F. Boersma 


\section{References}

Acarreta, J. R., de Haan, J. F., and Stammes, P.: Cloud pressure retrieval using the $\mathrm{O}_{2}-\mathrm{O}_{2}$ absorption band at $477 \mathrm{~nm}$, J. Geophys. Res., 109, 05204, doi:10.1029/2003JD003915, 2004.

Bak, J., Kim, J. H., Spurr, R. J. D., Liu, X., and Newchurch, M. J.: Sensitivity study of ozone retrieval from UV measurements on geostationary platforms, Remote Sens. Environ., 118, 309-319, 2012a.

Bak, J., Liu, X., Wei, J., Pan, L., Chance, K., and Kim, J. H.: Improvement of OMI ozone profile retrievals in the upper troposphere and lower stratosphere by the use of a tropopause based ozone profile climatology, Atmos. Meas. Tech., submitted, 2012 b.

Bhartia, P. K. and Wellemeyer, C. W.: TOMS-V8 total O3 algorithm, OMI Algorithm, Theoretical Basis Document vol. II, NASA Goddard Space Flight Center, Greenbelt, MD, 2387 pp., 2002.

Bhartia, P. K., McPeters, R. D., Mateer, C. L., Flynn, L. E., and Wellemeyer, C.: Algorithm for the estimation of vertical ozone profiles from the backscattered ultraviolet technique, J. Geophys. Res., 101, 18793-18806, 1996.

Bovensmann, H., Burrows, J. P., Buchwitz, M., Frerick, J., Noël, S., Rozanov, V. V., Chance, K. V., and Goede. A. P. H.: SCIAMACHY: mission objectives and measurement modes, J. Atmos. Sci., 56, 127-150, 1999.

Bovensmann, H., Eichmann, K. U., Noel, S., Rozanov, V., Vountas, M., and Burrows., J. P.:EUMETSAT contract EUM/CO/03/1166/SAT, Final Report, available at: http://www.eumetsat.int/groups/pps/documents/document/ pdf_mtg_rep09.pdf, 2004.

Caspar, C. and Chance, K.: GOME wavelength calibration using solar and atmospheric spectra, paper presented at third ERS Symposium on Space at the Service of our Environment, Florence, Italy, 14-21 March, 1997.

Cai, Z., Liu, Y., Liu, X., Chance, K., Nowlan, C. R., Lang, R., Munro, R., and Suleiman, R.: Characterization and correction of global ozone monitoring experiment 2 ultraviolet measurements and application to ozone profile retrievals, J. Geophys. Res., 117, 07305, doi:10.1029/2011JD017096, 2012.

Chance, K.: Analysis of BrO measurements from the global ozone monitoring experiment, Geophys. Res. Lett., 25, 3335-3338, 1998.

Chance, K.: Ultraviolet and visible spectroscopy and spaceborne remote sensing of the Earth's atmosphere, C. R. Phys., 6, 836847, 2005.

Chance, K.: Spectroscopic measurements of tropospheric composition from satellite measurements in the ultraviolet and visible: steps toward continuous pollution monitoring from space, in: Remote Sensing of the Atmosphere for Environmental Security, edited by: Perrin, A., Ben Sari-Zizi, N., and Demaison, J., P.O. Box 17, 3300 AA Dordrecht, The Netherlands, NATO Security through Science Series, ISBN: 1-4020-5089-5, Springer, 1-25, 2006.

Chance, K. V., Burrows, J. P., Perner, D., and Schneider, W.: Satellite measurements of atmospheric ozone profiles, including tropospheric ozone, from ultraviolet/visible measurements in the nadir geometry: a potential method to retrieve tropospheric ozone, J. Quant. Spectrosc. Ra., 57, 467-476, 1997.
Crutzen, P. J.: My life with $\mathrm{O}_{3}, \mathrm{NO}_{\mathrm{x}}$, and other $\mathrm{YZO}_{\mathrm{X}}$ Compounds, Angew. Chem., Int. Ed. Engl., 35, 1758-1777, 1996.

Dobber, M., Kleipool, Q., Dirksen, R., Levelt, P., Jaross, G., Taylor, S., Kelly, T., Flynn, L., Leppelmeier, G., and Rozemeijer, N.: Validation of Ozone Monitoring Instrument level $1 \mathrm{~b}$ data products, J. Geophys. Res., 113, D15S06, doi:10.1029/2007JD008665, 2008. European Space Agency: The GOME Users Manual, edited by: Bednarz, F., European Space Agency Publication SP-1182, ESA Publications Division, ESTEC, Noordwijk, The Netherlands, ISBN-92-9092-327-x, 1995.

Fishman, J., Iraci, L. T., Al-Saadi, J., Chance, K., Chavez, F., Chin, M., Coble, P., Davis, C.,DiGiacomo, P. M., Edwards, D., Eldering, A., Goes, J., Herman, J., Hu, C., Jacob, D., Jordan,C., Kawa, S. R., Key, R., Liu, X., Lohrenz, S., Mannino, A., Natraj, V., Neil, D., Neu, J., Newchurch, M., Pickering, K., Salisbury, J., Sosik, H., Subramaniam, A., Tzortziou, M., Wang, J., and Wang, M.: The United States' Next Generation of Atmospheric Composition and Coastal Ecosystem Measurements: NASA's Geostationary Coastal and Air Pollution Events (GEO-CAPE) Mission, Am. Meterol. Soc., doi:10.1175/BAMS-D-11-00201.1, in press, 2012.

Froidevaux, L., Jiang, Y. B., Lambert, A., Livesey, N. J., Read, W. G., Waters, J. W., Browell, E. V., Hair, J. W., Avery, M. A., McGee, T. J., Twigg, L.W., Sumnicht, G. K., Jucks, K.W., Margitan, J. J., Sen, B., Stachnik, R. A., Toon, G. C., Bernath, P.F., Boone, C. D., Walker, K. A., Filipiak, M. J., Harwood, R. S., Fuller, R. A., Manney, G. L., Schwartz, M. J., Daffer, W. H., Drouin, B. J., Cofield, R. E., Cuddy, D. T., Jarnot, R. F., Knosp, B. W., Perun, V. S., Snyder, W. V., Stek, P. C., Thurstans, R. P., and Wagner, P. A.: Validation of Aura Microwave Limb Sounder stratospheric ozone measurements, J. Geophys. Res., 113, D15S20, doi:10.1029/2007JD008771, 2008.

Haigh, J. D.: The role of stratospheric ozone in modulating the solar radiative forcing of climate, Nature, 370, 544-546, doi:10.1038/370544a0, 1994.

Hauglustaine, D. A. and Brasseur, G. P.: Evolution of tropospheric ozone under anthropogenic activities and associated radiative forcing of climate, J. Geophys. Res., 106, 32337-32360, doi:10.1029/2001JD900175, 2001.

Jiang, Y. B., Froidevaux, L., Lambert, A., Livesey, N. J., Read, W. G., Waters, J. W., Bojkov, B., Leblanc, T., McDermid, I. S., Godin-Beekmann, S., Filipiak, M. J., Harwood, R. S., Fuller, R. A., Daffer, W. H., Drouin, B. J., Cofield, R. E., Cuddy, D. T., Jarnot, R. F., Knosp, B. W., Perun, V. S., Schwartz, M. J., Snyder, W. V., Stek, P. C., Thurstans, R. P., Wagner, P. A., Allaart, M., Andersen, S. B., Bodeker, G., Calpini, B., Claude, H., Coetzee, G., Davies, J., De Backer, H., Dier, H., Fujiwara, M., Johnson, B., Kelder, H., Leme, N. P., önig-Langlo, G., Kyro, E., Laneve, G., Fook, L. S., Merrill, J., Morris, G., Newchurch, M., Oltmans, S., Parrondos, M. C., Posny, F., Schmidlin, F., Skrivankova, P., Stubi, R., Tarasick, D., Thompson, A., Thouret, V., Viatte, P., Vömel, H., von Der Gathen, P., Yela, M., and Zablocki, G.: Validation of aura microwave limb sounder ozone by ozonesonde and lidar measurements, J. Geophys. Res., 112, D24S34, doi:10.1029/2007JD008776, 2007.

Joiner, J. and Vasilkov, A. P.: First results from the OMI rotational Raman scattering cloud pressure algorithm, IEEE T. Geosci. Remote, 44, 1272-1282, 2006. 
Kim, J.: GEMS (Geostationary Environment Monitoring Spectrometer) onboard the GeoKOMPSAT to Monitor Air Quality in high Temporal and Spatial Resolution over Asia-Pacific Region, EGU General Assembly 2012, 22-27 April 2012, Vienna, Austria, p. 4051, 2012.

Kuhl, S., Pukite, J., Deutschmann, T., Platt, U., and Wagner, T.: SCIAMACHY limb measurements of $\mathrm{NO}_{2}, \mathrm{BrO}$ and OClO. Retrieval of vertical profiles: algorithm, first results, sensitivity and comparison studies, Adv. Space Res., 42, 1747-1764, 2008.

Kuttippurath, J., Lefèvre, F., Pommereau, J.-P., Roscoe, H. K., Goutail, F., Pazmiño, A., and Shanklin, J. D.: Antarctic ozone loss in 1989-2010: evidence for ozone recovery?, Atmos. Chem. Phys. Discuss., 12, 10775-10814, doi:10.5194/acpd-12-107752012, 2012.

Levelt, P. F., van den Oord, G. H. J., Dobber, M. R., Malkki, A., Visser, H., de Vries, J., Stammes, P., Lundell, J. O. V., and Saari, H.: The ozone monitoring instrument, IEEE T. Geosci. Remote, 44, 1093-1101, 2006.

Liu, S. C. and Trainer, M.: Responses of the tropospheric ozone and odd hydrogen radicals to column ozone change, J. Atmos. Chem., 6, 221-233, doi:10.1007/BF00053857, 1987.

Liu, X., Chance, K., Sioris, C. E., Spurr, R. J. D., Kurosu, T. P., Martin, R. V., and Newchurch, M. J.: Ozone profile and tropospheric ozone retrievals from global ozone monitoring experiment: algorithm description and validation, J. Geophys. Res., 110, 20307, doi:10.1029/2005JD006240, 2005.

Liu, X., Bhartia, P. K., Chance, K., Spurr, R. J. D., and Kurosu, T. P.: Ozone profile retrievals from the Ozone Monitoring Instrument, Atmos. Chem. Phys., 10, 2521-2537, doi:10.5194/acp-10-25212010, 2010a.

Liu, X., Bhartia, P. K., Chance, K., Froidevaux, L., Spurr, R. J. D., and Kurosu, T. P.: Validation of Ozone Monitoring Instrument (OMI) ozone profiles and stratospheric ozone columns with Microwave Limb Sounder (MLS) measurements, Atmos. Chem. Phys., 10, 2539-2549, doi:10.5194/acp-10-2539-2010, $2010 \mathrm{~b}$.

Livesey, N. J., Filipiak, M. J., Froidevaux, L., Read, W. G., Lambert, A., Santee, M. L., Jiang, J. H., Pumphrey, H. C., Waters, J. W., Cofield, R. E., Cuddy, D. T., Daffer, W. H., Drouin, B. J., Fuller, R. A., Jarnot, R. F., Jiang, Y. B., Knosp, B. W., Li, Q. B., Perun, V. S., Schwartz, M. J., Snyder, W. V., Stek, P. C., Thurstans, R. P., Wagner, P. A., Avery, M., Browell, E. V., Cammas, J. P., Christensen, L. E., Diskin, G. S., Gao, R. S., Jost, H. J., Loewenstein, M., Lopez, J. D., Nedelec, P., Osterman, G. B., Sachse, G. W., and Webster, C. R.: Validation of aura microwave limb sounder $\mathrm{O}_{3}$ and $\mathrm{CO}$ observations in the upper troposphere and lower stratosphere, J. Geophys. Res., 113, D15S02, doi:10.1029/2007JD008805, 2008.

Livesey, N. J., Read, W. G., Froidevaux, L., Lambert, A., Manney, G. L., Pumphrey, H. C., Santee, M. L., Schwartz, M. J., Wang, S., Cofeld, R. E., Cuddy, D. T., Fuller, R. A., Jamot, R. F., Jiang, J. H., Knosp, B. W., Stek, P. C., Wagner, P. A., and Wu, D. L.: Version 3.3 Level 2 data quality and description document, JPL California Institute of Technology, Pasadena, California, 911098099, 2011.

McPeters, R. D. and Labow, G. J.: Climatology 2011: an MLS and sonde derived ozone climatology for satellite retrieval algorithms, J. Geophys. Res., 1117, 10303, doi:10.1029/2011JD017006, 2012.
McPeters, R. D., Bhartia, P. K., Krueger, A. J., and Herman J. R.: Earth probe total ozone mapping spectrometer (TOMS) data products user's guide, NASA Goddard Space Flight Center, Greenbelt, Maryland 20771, 1998.

McPeters, R. D., Labow, G. J., and Logan, J. A.: Ozone climatological profiles for satellite retrieval algorithms, J. Geophys. Res., 112, D05308, doi:10.1029/2005JD006823, 2007.

Munro, R., Siddans, R., Reburn, W., and Kerridge, B.: Direct measurement of tropospheric ozone distributions from space, Nature, 392, 168-171, 1998.

Natraj V., Liu, X., Kulawik, S. S., Chance, K., Chatfield, R., Edwards, D. P, Eldering, A., Francis, G., Kurosu, T., Pickering, K., Spurr, R., and Worden, H.: Multispectral sensitivity studies for the retrieval of tropospheric and lowermost tropospheric ozone from simulated clear sky GEO-CAPE measurements, Atmos. Environ., 45, 7151-7165, doi:10.1016/j.atmosenv.2011.09.014, 2011.

Rodgers, C. D.: Inverse Methods for Atmospheric Sounding: Theory and Practice, World Scientific Publishing, Singapore, 2000.

Saiz-Lopez, A., Chance, K. V., Liu, X., Kurosu, T. P., and Sander, S. P.: First observations of iodine oxide from space, Geophys. Res. Lett., 34, 12812, doi:10.1029/2007GL030111, 2007.

Salby, M., Titova, E., and Deschamps, L.: Rebound of Antarctic ozone, Geophys. Res. Lett., 5, 09702, doi:10.1029/2011GL047266, 2011.

van $\operatorname{der}$ A, R. J., van Oss, R. F., Piters, A. J. M., Fortuin, J. P. F., Meijer, Y. J., and Kelder, H. M.: Ozone profile retrieval from recalibrated GOME data, J. Geophys. Res., 107, 4239, doi:10.1029/2001JD000696, 2002.

van Oss, R. F., Voors, R. H. M., and Spurr, R. J. D.: Ozone profile algorithm, in OMI Algorithm Theoretical Basis Document, Vol. 2, OMI Ozone Products, edited by: Bhartia, P. K., 51-73, NASA Goddard Space Flight Cent., Greenbelt, Md, 2001.

Vasilkov, A. P., Joiner, J., Yang, K., and Bhartia P. K.: Improving total column ozone retrievals by using cloud pressures derived from Raman scattering in the UV, Geophys. Res. Lett., 31, 20109, doi:10.1029/2004GL020603, 2004.

Vasilkov, A., Joiner, J., Spurr, R., Bhartia, P. K., Levelt, P., and Stephens, G.: Evaluation of the OMI cloud pressures derived from rotational Raman scattering by comparisons with other satellite data and radiative transfer simulations, J. Geophys. Res., 113, D15S19, doi:10.1029/2007JD008689, 2008.

Worden, J., Liu, X., Bowman, K., Chance, K., Beer, R., Eldering, A., Gunson, M., and Worden, H.: Improved tropospheric ozone profile retrievals using OMI and TES radiances, Geophys. Res. Lett., 34, 01809, doi:10.1029/2006GL027806, 2007.

Zoogman, P., Jacob, D. J., Chance, K., Zhang, L., Sager, P. L., Fiore, A. M., Eldering, A., Liu, X., Natraj, V., and Kulawik, S. S.: Ozone air quality measurement requirements for a geostationary satellite mission, Atmos. Environ., 45, 7143-7150, doi:10.1016/j.atmosenv.2011.05.058, 2011. 